\title{
Correction to: Histiocyte-rich rhabdomyoblastic tumor: a report of two cases and a review of the differential diagnoses
}

\author{
Melanie Bourgeau ${ }^{1}$ - Anthony P. Martinez ${ }^{1,2}$ (D) \\ Published online: 22 June 2020 \\ (C) Springer-Verlag GmbH Germany, part of Springer Nature 2020
}

\section{Correction to: Virchows Archiv https://doi.org/10.1007/s00428-020-02857-x}

The given name of the co-author of the article mentioned above was incorrectly spelled. The correct name should have been "Melanie Bourgeau" instead of "Melanine Bourgeau." The original article has been corrected.

Publisher's note Springer Nature remains neutral with regard to jurisdictional claims in published maps and institutional affiliations.

The online version of the original article can be found at https://oi.org/ $10.1007 / \mathrm{s} 00428-020-02857-\mathrm{x}$

\footnotetext{
Anthony P. Martinez

anthonymartinezmd@gmail.com

1 Department of Pathology and Laboratory Medicine, Emory University, Atlanta, GA 30322, USA

2 Department of Dermatology, Emory University, Atlanta, GA 30322, USA
} 